\title{
MEASURING EFFICIENCY OF TEACHING PROCESS AND FACULTY IN TRANSITION STATES USING DEA ANALYSIS
}

\author{
Veselin Perovic, Ranko Bojanic, Branislav Nerandzic
}

Original scientific paper The aim of this study is to examine the relative efficiency of the teaching process (study) at the largest faculty in Serbia based on enveloped data (DEA analysis). The analysis was conducted in the 2013/14 academic year and includes 863 graduate students who have completed their studies in 13 academic programs. Input variables used in this analysis were the average secondary school grade and the number of scores earned on the entrance exam, while the output variables were the average grade achieved during the study and the length of study. Our approach integrates the DEA (Data Envelopment Analysis) approach and the statistical analysis of variance with the aim of developing an expanded model for measuring the efficiency of the teaching process Measurements of efficiency of higher education institutions will be presented using the DEA analysis in measuring the efficiency of each student individually and measuring the efficiency of students of specific study programs or faculties. Efficiency of studying which is measured for each student individually is over $70 \%$, while the efficiency of study programs is over $85 \%$. The efficiency of studying was measured on the example of a faculty consisting of 13 departments and 17 study programs of basic academic studies. As per the law there are no integrated universities in the Republic of Serbia but each faculty is a separate institution, each department of the Faculty of Technical Sciences can be considered a separate faculty, while the faculty itself can be considered a university. Thus, this analysis can describe the measurement of efficiency of the university.

Keywords: DEA analysis; efficiency of studing; teching process

Mjerenje učinkovitosti edukacijskog procesa fakulteta u tranzicijskim zemljama uporabom DEA analize

Izvorni znanstveni članak

U ovoj studiji koristi se DEA analiza, radi ispitivanja relativne učinkovitosti nastavnog procesa studiranja na najvećem fakultetu u Srbiji: Analiza je provedena tijekom ak. godine 2013/14. Studijom je obuhvaćeno 863 diplomirana studenta koji su završili studije na 13 studijskih programa. Ulazne varijable koje su korištene u ovoj analizi su srednja ocjena iz srednje škole i broj osvojenih bodova na kvalifikacijkom ispitu, a izlazne varijable prosječne ocjene ostvarene tijekom studija kao i duljina studiranja. Naš pristup integrira DEA - Data Envelopment Analysis i statističku analizu varijanci, a u cilju razvijanja proširenog modula za mjerenje učinkovitosti nastavnog procesa. Mjerenje učinkovitosti visokoškolskih ustanova prikazat ćemo primjenom DEA analize u mjerenju učinkovitosti svakog studenta posebno i kao mjerenje učinkovitosti studenata određenih studijskih programa, odnosno fakulteta. Učinkovitost studiranja koja se mjeri za svakog studenta pojedinačno je preko $70 \%$, a kada se radi o mjerenju učinkovitosti i studijskih programa učinkovitost je preko 85\%. Mjerenje učinkovitosti studiranja je napravljeno na primjeru fakulteta koji u svom sustavu ima 13 departmana i 17 studijskih programa osnovnih akademskih studija. Kako po zakonu Republike Srbije ne postoje integrirana sveučilišta već je svaki fakultet zasebna ustanova, svaki departman Fakulteta tehničkih nauka se možemo posmatrati kao zaseban fakultet, a sam fakultet kao sveučilište. Na taj način ovom analizom možemo prikazati mjerenje učinkovitosti sveučilišta.

Ključne riječi: DEA analiza; edukativni proces; učinkovitost studiranja

\section{Introduction}

The environment in which universities in the Republic of Serbia operate has changed considerably since 2005, when the reforms were introduced in this area based on the Law on Higher Education. The first steps in these reforms were already visible in 2007 when the new way of studying started with shifting to the system of $3+$ 1 years of study and providing accreditation for first study programs and institutions. Improving the quality of studies became the core requirement imposed to universities; at the same time there are budget constraints faced by all state-owned universities. All this requires faculty administrations to improve the quality of studies despite the scarce resources. They are primarily required to shorten the time of studying at all faculties because at some point at some faculties where studies should last 5 years it amounted to as much as 12 years of studying.

This research proposes an instrument for measuring the efficiency of the teaching process and studying for both individual students and the overall study program with the aim of raising the quality of the teaching process. The paper introduces a new model of efficiency of the teaching process based on the Data Envelopment Analysis (DEA) methodology developed by [1] Charnes, Cooper, and Rhodes (1978). The specific objective of this model is to determine: (A) the overall efficiency of studying for each student individually who graduated in the same school year; (B) the efficiency of the teaching process measured for each student individually and the efficiency of the teaching process by study programs; (C) objectives with a variety of input and output values, which will show the efficiency of the teaching process in a more realistic way because they include dimensions such as the percentage of passing the exams and the ratio of students graduated and students enrolled.

One of the main advantages of this model is its ability to assess the overall efficiency of the teaching process for each study program, as well as the efficiency of the teaching process for each student individually on the basis of different inputs relative to outputs. For this reason, this method is suitable for use in education and universities because the complexity of the manufacturing processes and the lack of information on both the input and output parameters. With all these problems, this model provides an objective and adequate instrument for measuring the efficiency at universities and faculties. Similar topics can be found in literature in $[2 \div 8]$ However, there are few papers analysing the efficiency of the teaching process based on the input and output values that were used in the present paper, and there are few such papers in the economic sector. Higher education in the Republic of Serbia is based on traditionalism and conventionalism, while the criteria of market economy, such as making 
education as cheap as possible and raising the profitability of studies, are ignored. The process of studying should be more efficient and cost effective, because the state has no interest in investing money in something that takes many years rather than 4 or 5 years as it should be.

DEA models are an excellent tool for a reliable assessment of efficiency of the teaching process or the overall university. Studies in the world on this subject are different from works in this field in our country. Among the authors who have written on this subject, we can mention $[7,8]$.

\section{The DEA method}

The data envelopment analysis (DEA) was originally introduced by Charnes, Cooper and Rhodes (1978) and it is a non-parametric linear programming approach which allows multiple inputs and multiple outputs to be processed. More specifically, this approach allows different types of inputs and outputs to be analyzed simultaneously.

The DEA model can be constructed either to minimize the inputs or to maximize the outputs. The input oriented model is aimed at reducing the amount of inputs as much as possible while maintaining the lowest existing levels of outputs, while the output oriented model aims to maximize the output levels without increasing the number of inputs used [9]

In DEA terminology, the organization whose efficiency should be evaluated is called "decision making unit" (DMU) [10] The basic concept of DEA analysis is measuring the efficiency of a specific decision making unit (DMU) in relation to the projected point on the 'efficiency frontier' [11]. Creators of DEA analysis (Charnes, Cooper and Rhodes) proposed a non-parametric approach to calculate efficiency by reducing multiple inputs to a single "virtual" output using weight coefficients.

They solved the problem of assigning weights by allowing each unit to determine its own weight in order to maximize its efficiency (the ratio of its input and output weight sum), with the restriction that the weights should be of positive values and that the quotient of the virtual output and virtual input of the unit cannot be greater than 1. This problem is defined as a linear programming task which is known as "CCR ratio model" [12]

Based on the input and output variable data, the data envelopment analysis determines whether an item on which a decision should be made is efficient or not relative to the remaining units of the analysis, i.e. whether it is on the efficiency frontier or not. In economic terms, efficiency frontier is an empirically derived maximum value of output variables, achievable by each decision unit with a given input variable and acts as an envelope for inefficient units. It is believed that 'objectivity' is the main advantage of this method, because it is free of subjective opinions as opposed to customer satisfaction surveys where survey is used as research instrument. However, weights determined by DEA analysis sometimes can be inconsistent with the prior knowledge or accepted viewpoints for the relative values of inputs and outputs
The DEA model is formulated in the form of the following tasks:

$\operatorname{Max}\left(E f f_{m}=\frac{\sum_{k} u_{k} y_{k m}}{\sum_{i} v_{i} x_{i m}}\right)$

with the restriction that

$$
\frac{\sum_{k} u_{k} y_{k i}}{\sum_{i} v_{i} x_{i j}} \geq 1 \quad u_{k}, v_{i} \geq 0
$$

with the following meaning: maximize the efficiency of the $m^{\text {th }}$ unit with restriction that the efficiency of all units is $<1$.The linear version of the model is:

$$
\begin{aligned}
& \operatorname{Max}\left(E f f_{j}=\sum_{k} v_{k} y_{k m}\right) \\
& \sum_{i} u_{i} x_{i m}=b \\
& \sum_{k}^{i} v_{k} y_{k j}-\sum_{i} u_{i} x_{i j} \leq 0, \quad \forall j \\
& v_{k}, u_{i} \geq 0 \text { or } \varepsilon
\end{aligned}
$$

where:

$y_{k j}-$ value of the $k^{\text {th }}$ output of the $j^{\text {th }}$ unit, $v_{k}$ - weight associated to the $k^{\text {th }}$ output, $x_{i j}$ - value of the $i^{\text {th }}$ input into the $j^{\text {th }}$ unit,

$u_{i}$ - weight of the $i^{\text {th }}$ input,

$b$ - constant,

$E f f_{j}$ - efficiency of the $j^{\text {th }}$ unit

$\varepsilon-$ a small value, it may be introduced in order to avoid some input or output to be excluded from determining efficiency.

Resolving the model's linear version determines the efficiency of the target $\left(m^{\text {th }}\right)$ unit. The obtained weight values $(u, v)$ are the best from the perspective of the $m^{\text {th }}$ unit. Weights obtained for any two units can be different since the criterion functions are different. If the observed unit is efficient with its optimal values of weight coefficient, other unit cannot achieve a higher value of output variables for the given input variables. If the unit is inefficient, this is not the case. Data for diverse input and output variables are usually with a very wide range of values. If the DEA model is invariant to the units of measurement, we can resort to data scaling [14]

\section{Higher education in the Republic of Serbia}

In the last two decades, higher education is characterized by quantitative expansion, which is not accompanied by increase but deterioration of quality, and significant financial limitations. When speaking about Serbia, the expansion is particularly pronounced given many private universities and faculties which emerged overnight. Faculties and universities are generally established for professions which require the least 
investments and where funds for the operation are the easiest to provide. Most of the faculties are in the fields of economics, management, business, law, etc., while the least or almost none of them are in the fields of medicine, mechanical engineering, electrical engineering, i.e. in the field of science and technology. One of the reasons that led to this situation is the fact that the state still funds only public universities, while private universities are left to their own devices. This is becoming increasingly detrimental to the overall functioning of higher education and leads to a decline in the quality of teaching staff, which is a hindrance to research, even in countries with strong academic foundations and tradition. In this case, the gap between developed countries and developing countries is becoming more profound because it is impossible to maintain the balance of technological and scientific development.

Quantitative expansion of higher education is evident when analysing the data on the number of students enrolled in this period. The European Union has published the fact that $25 \%$ of its citizens held higher education degree in 2007. When analysing the data of individual EU member states, it is evident that the EU education also holds its own gap. Scandinavia and the Benelux states have the highest percentage of population with a degree in high education (30\% to $36.4 \%)$. Also there is a high share of population with higher education in Ireland, whose model of education is one of the most recognized in the world. In Germany, the most developed EU country, this share is $24.3 \%$, which is less than the EU average. Greece and Turkey are on the other side where the share of population with a degree in higher education is only $22.7 \%$ and $10 \%$, respectively [15].

And where is Serbia? At the very bottom of the European scale, with $6 \%$ of population with a degree in higher education or $11 \%$, of those completed some form of higher education. When speaking of countries of former Yugoslavia, only Bosnia and Herzegovina has a smaller percentage than Serbia. From the neighbouring countries, the highest percentage of population with a university degree is that of Slovenia (22\%), Croatia (15\%) and Macedonia (7.3\%) (Fig. 5). It is believed that an average developed country needs to have at least $20 \%$ of the population holding a university degree

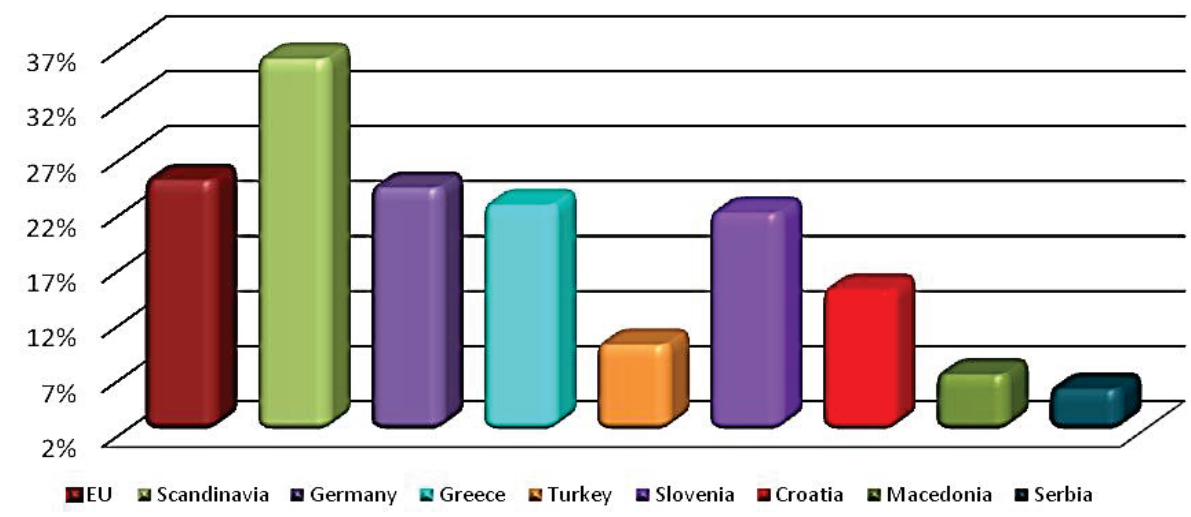

Figure 1 The share of population holding a degree in higher education (www.oecd.org/edu)

About $45 \%$ of students never complete their studies, while those who graduate do so, on average, two years longer than foreseen by the study program. The deep changes in institutional structures and forms of high education, as well as in methods of teaching, training and learning, are introduced by the state government or institutions themselves. In the higher education space of the Republic of Serbia there are currently 8 public universities: 7 non-integrated universities and one integrated, and 9 universities owned by private capital. One of them is the Faculty of Technical Sciences in Novi Sad, which is composed of 13 departments that can represent individual faculties. The faculty has 28 study programs of undergraduate academic studies and 33 programs of master academic studies.

\section{DEA model for measuring the efficiency of the educational process for each student individually}

The study of efficiency of the teaching process has been conducted at the Faculty of Technical Sciences in Novi Sad, and includes 863 graduated engineers, who completed their studies at one of the 17 current study programs. The subject of one of the previous research was measuring the efficiency of teaching process for each graduate student individually. This analysis will improve these results and expand them with new insights, as it presents the measurement of efficiency of the teaching process at each of the study programs, indicating thus the performance of departments. First, we present the DEA model in which we analyse the ways in which variables of average secondary school grades and scores on the entrance exam affects the output variable of the length of the study and average grade during the studies for each student individually. Taking into account that the average duration of study in Serbia is about 8 years, which is twice longer than foreseen, it is necessary to determine the reasons. In this analysis, besides the above input and output variables, the average length of studying and the percentage of passing the exams for each study program will be used as additional output variables. In the first model we will present the efficiency of studies of 863 graduate students in 17 study programs. The data were analysed using the Max DEA software v. 6.3. Due to the volume of research only individual benchmarks of this data analysis will be presented.

The procedure of application of the DEA method for measuring the efficiency of the teaching process consists of three phases [16]

1) Defining and selecting the units whose relative efficiency should be determined - in this case, the teaching process. 
2) Determining the input and output variables that are relevant and suitable for assessing the relative efficiency of selected decision making units. Input dimensions are average secondary school grades and scores on the entrance exam, while the results achieved during the study make the outputs. Selecting the adequate DEA model and resolving the DEA model, analysis and interpretation of results. This study used the envelopment model DEA.

\subsection{The first DEA model}

In the first DEA model, two input and two output variables were considered, with secondary school grades and scores at the entrance exam being the input variables, and average grade during the study and the length of study being the output variables.

$\operatorname{Max}\left(E f f_{m}=\frac{\sum_{r=1}^{s} u_{r} y_{r m}}{\sum_{i=1}^{n} v_{i} x_{i m}}\right)$

$s=1,2 \quad n=1,2$

Tab. 1 shows their values. Values of all variables are in a wide range; thus, the data were scaled [17]

Table 1 Student efficiency levels in the first DEA model

\begin{tabular}{|c|c|c|c|}
\hline DMU & Score & Output Inefficiency & Output Radial Inefficiency \\
\hline Student 140 & 1.000 & 0.000 & 0.000 \\
\hline Student 247 & 1.000 & 0.000 & 0.000 \\
\hline Student 248 & 1.000 & 0.000 & 0.000 \\
\hline Student 260 & 1.000 & 0.000 & 0.000 \\
\hline Student 262 & 1.000 & 0.000 & 0.000 \\
\hline Student 266 & 1.000 & 0.000 & 0.000 \\
\hline Student 269 & 1.000 & 0.000 & 0.000 \\
\hline Student 273 & 1.000 & 0.000 & 0.000 \\
\hline Student 42 & 1.000 & 0.000 & 0.000 \\
\hline Student 47 & 1.000 & 0.000 & 0.000 \\
\hline Student 515 & 1.000 & 0.000 & 0.000 \\
\hline Student 614 & 1.000 & 0.000 & 0.000 \\
\hline Student 683 & 1.000 & 0.000 & 0.000 \\
\hline Student 711 & 1.000 & 0.000 & 0.000 \\
\hline Student 740 & 1.000 & 0.000 & 0.000 \\
\hline Student 78 & 1.000 & 0.000 & 0.000 \\
\hline Student 798 & 1.000 & 0.000 & 0.000 \\
\hline Score & Number of students & Output Inefficiency & Output Radial Inefficiency \\
\hline $0.999 \div 0.990$ & 16 & $0.001 \div 0010$ & $0.001 \div 0010$ \\
\hline $0.989 \div 0.980$ & 7 & $0.012 \div 0.019$ & $0.012 \div 0.019$ \\
\hline $0.979 \div 0.970$ & 13 & $0.022 \div 0.031$ & $0.022 \div 0.031$ \\
\hline $0.969 \div 0.960$ & 15 & $0.034 \div 0.042$ & $0.034 \div 0.042$ \\
\hline $0.959 \div 0.950$ & 16 & $0.043 \div 0.053$ & $0.043 \div 0.053$ \\
\hline $0.949 \div 0.940$ & 28 & $0.054 \div 0.064$ & $0.054 \div 0.064$ \\
\hline $0.939 \div 0.930$ & 28 & $0.065 \div 0.076$ & $0.065 \div 0.076$ \\
\hline $0.929 \div 0.920$ & 28 & $0.077 \div 0.087$ & $0.077 \div 0.087$ \\
\hline $0.919 \div 0.910$ & 31 & $0.088 \div 0.100$ & $0.088 \div 0.100$ \\
\hline $0.909 \div 0.900$ & 36 & $0.101 \div 0.111$ & $0.101 \div 0.111$ \\
\hline $0.899 \div 0.890$ & 24 & $0.112 \div 0.123$ & $0.112 \div 0.123$ \\
\hline $0.889 \div 0.880$ & 29 & $0.125 \div 0.137$ & $0.125 \div 0.137$ \\
\hline $0.879 \div 0.870$ & 28 & $0.138 \div 0.150$ & $0.138 \div 0.150$ \\
\hline $0.869 \div 0.860$ & 34 & $0.150 \div 0.163$ & $0.150 \div 0.163$ \\
\hline $0.859 \div 0.850$ & 25 & $0.165 \div 0.177$ & $0.165 \div 0.177$ \\
\hline $0.849 \div 0.840$ & 43 & $0.178 \div 0.191$ & $0.178 \div 0.191$ \\
\hline $0.839 \div 0.830$ & 33 & $0.193 \div 0.205$ & $0.193 \div 0.205$ \\
\hline $0.829 \div 0.820$ & 41 & $0.206 \div 0.219$ & $0.206 \div 0.219$ \\
\hline $0.819 \div 0.810$ & 42 & $0.220 \div 0.234$ & $0.220 \div 0.234$ \\
\hline $0.809 \div 0.800$ & 41 & $0.235 \div 0.250$ & $0.235 \div 0.250$ \\
\hline $0.799 \div 0.790$ & 43 & $0.251 \div 0.266$ & $0.251 \div 0.266$ \\
\hline $0.789 \div 0.780$ & 36 & $0.267 \div 0.282$ & $0.267 \div 0.282$ \\
\hline $0.779 \div 0.770$ & 38 & $0.283 \div 0.299$ & $0.283 \div 0.299$ \\
\hline $0.769 \div 0.760$ & 41 & $0.300 \div 0.316$ & $0.300 \div 0.316$ \\
\hline $0.759 \div 0.750$ & 43 & $0.318 \div 0.334$ & $0.318 \div 0.334$ \\
\hline $0.749 \div 0.740$ & 29 & $0.335 \div 0.351$ & $0.335 \div 0.351$ \\
\hline $0.739 \div 0.730$ & 26 & $0.353 \div 0.370$ & $0.353 \div 0.370$ \\
\hline $0.729 \div 0.720$ & 21 & $0.373 \div 0.429$ & $0.373 \div 0.429$ \\
\hline $0.699 \div 0.690$ & 2 & $0.434 \div 0.443$ & $0.434 \div 0.443$ \\
\hline
\end{tabular}


Analysing the input values of average secondary school grades and scores on the entrance exam it was found that 17 students who studied at various study programs have the same study efficiency: 1 . Due to the volume of data - 863 students were analysed - other scores, instead of being provided individually, they were grouped in Score frequencies in intervals of 0.010 . We found that the efficiency of studies is very high: of the 863 respondents 245 students have the efficiency higher than 0.90 , while 340 students have the efficiency higher than 0.80 .

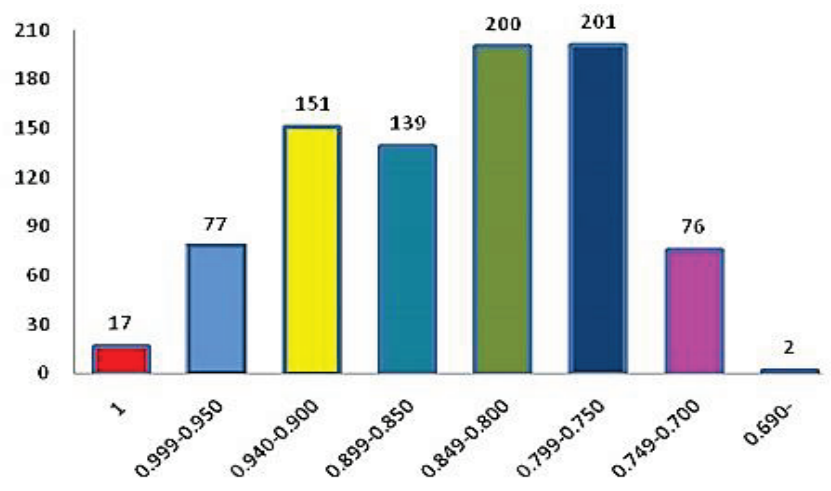

\begin{tabular}{|c|c|}
\hline \multicolumn{2}{|c|}{ Score frequencies } \\
\hline up to 0.10 & 0 \\
\hline $0.10+$ to 0.20 & 0 \\
\hline $0.20+$ to 0.30 & 0 \\
\hline $0.30+$ to 0.40 & 0 \\
\hline $0.40+$ to 0.50 & 0 \\
\hline $0.50+$ to 0.60 & 0 \\
\hline $0.60+$ to 0.70 & 2 \\
\hline $0.70+$ to 0.80 & 276 \\
\hline $0.80+$ to 0.90 & 340 \\
\hline $0.90+$ to 1.00 & 245 \\
\hline & 863 \\
\hline
\end{tabular}

Figure 2 Frequencies of efficiency of teaching process of the first DEA model

Based on this analysis, the efficiency of this higher education institution is very high.

Seventeen students achieved efficiency of 1, while 245 (about 28\%) have the efficiency higher than 0.90 . The research pointed out that any efficiency higher than 0.70 is satisfactory from the aspect of studying; in this analysis only two students failed to meet this criterion. Based on the analysis of individual student efficiency we can measure the performance of secondary schools, because the efficiency levels of students from each school in the process of studying are easy to see. In addition, study programs with most efficient students can be distinguished, and thus it can be determined whether good performance results from knowledge obtained in the secondary school or the teaching process at faculty. If a large number of students with maximum efficiency come from the same study program, studying in that particular program is clearly adapted to these students, regardless of knowledge obtained in secondary school [18].

By reviewing the most efficient students, it is concluded that out of 17 students with efficiency of 1 , five students are taught study program of Power, Electronics and Telecommunication Engineering, 4
Engineering Management, 2 Computer Engineering and Automation, 2 Traffic Engineering and Safety at Work, 1 Architecture, and 1 Energy and Process Engineering (Mechanical Engineering).

When analysing the efficiency by study programs, there is a doubt whether the study program with most efficient students is also the best one? This will be shown in the next model.

\subsection{The second DEA model - measuring the efficiency of study programs}

The efficiency of studying for each study program was examined using the same sample as in the previous model, where students were distributed to the 17 current study programs at bachelor studies. The results of 13 programs were presented in the analysis, given that 4 programs were not analysed due to the small number of students who were taught them. To make the sample adequate, the study programs completed by less than 10 students were classified to the error domain and were not analysed.

Table 2 Levels of efficiency of studying by study programs

\begin{tabular}{|c|c|c|c|}
\hline $\mathrm{NO}$ & DMU & Score & $\begin{array}{l}\text { Times as a benchmark for another } \\
\text { DMU }\end{array}$ \\
\hline 1. & Geodesy and Geomatics & 1 & 4 \\
\hline 2. & Engineering Management & 1 & 6 \\
\hline 3. & Mechatronics & 1 & 1 \\
\hline 4. & Postal Traffic and Telecommunications & 1 & 6 \\
\hline 5. & Environmental Engineering & 0.995345 & 0 \\
\hline 6. & Production Engineering & 0.987967 & 0 \\
\hline 7. & Traffic and Transport Engineering & 0.987834 & 0 \\
\hline 8. & Industrial Engineering & 0.963323 & 0 \\
\hline 9. & Graphic Engineering and Design & 0.943428 & 0 \\
\hline 10. & Computing and Control Engineering & 0.935818 & 0 \\
\hline 11. & Civil Engineering & 0.927905 & 0 \\
\hline 12. & Architecture & 0.912549 & 0 \\
\hline 13. & Power, Electronic and Telecommunication Engineering & 0.895966 & 0 \\
\hline
\end{tabular}

In the analysis of efficiency of studying by study programs the same parameters were used as in the analysis of individual students, with the exception that the percentage of graduates in relation to the number of 
students enrolled and the percentage of passing the exams were added to output values.

$$
\operatorname{Max}\left(E f f_{k}=\frac{\sum_{r=1}^{s} u_{r} y_{r k}}{\sum_{i=1}^{m} v_{i} x_{i k}}\right)
$$

$s=1,2,3,4$

$m=1,2$

The results obtained by measuring individual student efficiency, and student efficiency by study programs are diverse. The largest number of students with maximum efficiency of studying was taught the study program of Power, Electronics and Telecommunication Engineering (EET), while when measuring efficiency of study programs, it can be seen that this study program has the lowest efficiency of studying.

Also a considerable number of students with maximum efficiency are taught study program of Engineering Management (4 students), while this study program also achieved maximum efficiency. Perhaps, it is due to the number of students enrolled since the former program was enrolled by a much larger number of students than the latter; on the other hand, the number of students successfully graduating EET is also considerably low.

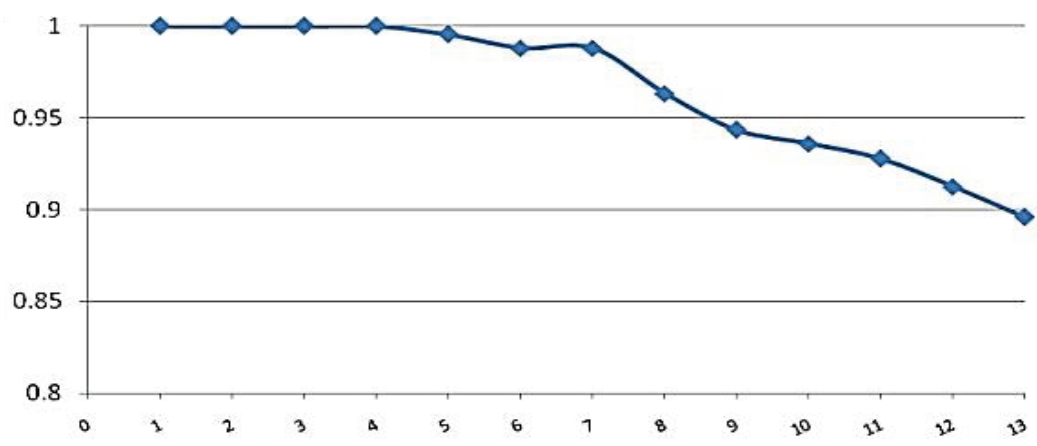

Figure 3 Levels of efficiency of studying by study programs measured using DEA

By analysing the input parameters for all study programs, it can be seen that students enrolling EET bring higher scores (36.87) than students enrolling engineering management (32.94), but the difference in scores on the entrance exam is reverse: the average realized on EET is 34.80 , while on engineering management it is 43.59 . Despite the higher grades, why are they performing worse on the entrance exam? The reason is in the difficulty of the entrance exam, as well as the difficulty of subsequent exams at these study programs, and hence the differences inefficiency of studying. This may be one of the problems of measuring the efficiency of studying for different study programs and therefore, we have chosen the model where the input parameters remain the same, while the output parameters are different, i.e. percentage of completion of the studies in the first and percentage of passing the exams in the second model.

\subsubsection{The first DEA model for measuring the efficiency percentage of graduate students}

In this analysis, the efficiency of studying was measured with secondary school grades and scores on the entrance exam being the input variables and the percentage of graduates compared to the number of enrolled student being the output variable. The comparison was conducted for the same group of students by examining their percentage of graduation and years of study.

The research has showed that the efficiency of studying, as measured by the percentage of graduate students in relation to the number of students enrolled per study programs, is rapidly decreasing. The difference is in the fact that in the previous measurement only the efficiency of graduate students was measured, while students who failed to complete their studies were not included. With this DEA analysis we have tried to correct this deficiency.

\subsubsection{DEA model for measuring the efficiency of percentage of passing the exams}

The efficiency of the process of studying can also be presented through measuring the efficiency of passing the exams, with secondary school grades and scores on the entrance exam as the input variables. DEA analysis allows measuring the knowledge obtained in secondary school. Based on their secondary education, students are opting for their study programs. This analysis would be most suitable for measuring both the performance of secondary schools and justification of taking entrance exams. Is the entrance exam authoritative for ranking students in enrolment or not? By analysing 13 study programs it can be seen that there are different groups of entrance exams and that students with better secondary school grades and knowledge perform worse on entrance exams. Therefore, it can be concluded that faculty entrance exam is an obsolete concept and thus, the results of the final matriculation exam which are employed by most countries in the region should be relevant. The matriculation exam is taken from the same subject matter by all the students and its difficulty is the same for all of them providing a much clearer picture of the school and efficiency of studying.

The DEA model for measuring the efficiency of passing the exams based on knowledge obtained in secondary school indicates rather high efficiency, except for one study program where it is lower than 0.8. This model results with similar data as in the generalized DEA 
model. Therefore, it can be concluded that secondary school grades are realistic and correspond to the actual knowledge of students.

Table 3 DEA analysis of efficiency of studying by measuring the percentage of graduate students

\begin{tabular}{|c|l|c|c|}
\hline \multicolumn{1}{|c|}{ DMU } & \multicolumn{1}{|c|}{ Score } & $\begin{array}{c}\text { Times as a benchmark } \\
\text { for another DMU }\end{array}$ \\
\hline 1. & \multicolumn{1}{|c|}{ Postal Traffic and Telecommunications } & 1.000 & 12 \\
\hline 2. & Engineering Management & 0.971 & 0 \\
\hline 3. & Architecture & 0.871 & 0 \\
\hline 4. & Computing and Control Engineering & 0.843 & 0 \\
\hline 5. & Environmental Engineering & 0.751 & 0 \\
\hline 6. & Traffic and Transport Engineering & 0.716 & 0 \\
\hline 7. & Geodesy and Geomatics & 0.709 & 0 \\
\hline 8. & Industrial Engineering & 0.689 & 0 \\
\hline 9. & Graphic Engineering and Design & 0.615 & 0 \\
\hline 10. & Power, Electronic and Telecommunication Engineering & 0.583 & 0 \\
\hline 11. & Mechatronics & 0.576 & 0 \\
\hline 12. & Production Engineering & 0.482 & 0 \\
\hline 13. & Civil Engineering & 0.426 & \\
\hline
\end{tabular}

Table 4 DEA analysis of efficiency of studying as measured by the percentage of passing the exams

\begin{tabular}{|c|l|c|c|}
\multicolumn{9}{|c}{ Table 4 DEA analysis of efficiency of studying as measured by the percentage of passing the exams } \\
\hline \multicolumn{1}{|c|}{ DMU } & \multicolumn{1}{|c|}{$\begin{array}{c}\text { Score } \\
\text { Times as a benchmark for another } \\
\text { DMU }\end{array}$} \\
\hline 1. & Geodesy and Geomatics & 1.000 & 8 \\
\hline 2. & Mechatronics & 1.000 & 2 \\
\hline 3. & Traffic and Transport Engineering & 1.000 & 4 \\
\hline 4. & Postal Traffic and Telecommunications & 0.989 & 0 \\
\hline 5. & Environmental Engineering & 0.966 & 0 \\
\hline 6. & Production Engineering & 0.963 & 0 \\
\hline 7. & Computing and Control Engineering & 0.949 & 0 \\
\hline 8. & Engineering Management & 0.933 & 0 \\
\hline 9. & Graphic Engineering and Design & 0.927 & 0 \\
\hline 10. & Industrial Engineering & 0.924 & 0 \\
\hline 11. & Architecture & 0.898 & 0 \\
\hline 12. & Power, Electronic and Telecommunication Engineering & 0.874 & \\
\hline 13. & Civil Engineering & 0.675 & \\
\hline
\end{tabular}

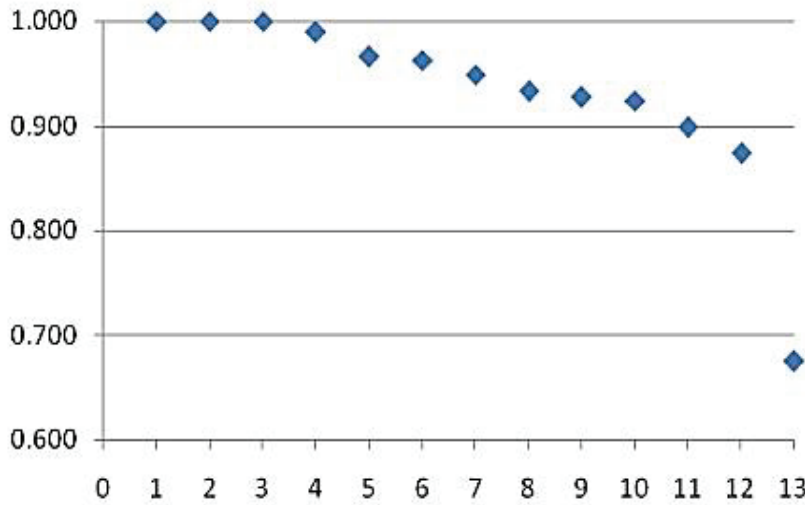

\begin{tabular}{|c|c|}
\hline \multicolumn{2}{|l|}{ Score frequencies } \\
\hline up to 0.10 & 0 \\
\hline $0.10+$ to 0.20 & 0 \\
\hline $0.20+$ to 0.30 & 0 \\
\hline $0.30+$ to 0.40 & 0 \\
\hline $0.40+$ to 0.50 & 0 \\
\hline $0.50+$ to 0.60 & 0 \\
\hline $0.60+$ to 0.70 & 1 \\
\hline $0.70+$ to 0.80 & 0 \\
\hline $0.80+$ to 0.90 & 2 \\
\hline $0.90+$ to 1.00 & 10 \\
\hline Suma & 13 \\
\hline
\end{tabular}

Figure 4 Graphic presentation of DEA analysis of efficiency of studying by measuring the percentage of passing the exams

\subsubsection{The second DEA model for measuring the efficiency of percentage of graduate students}

The following analysis shows how average rating of studying and completion of studies affects the efficiency of percentage of students graduated. From the aspect of ranking, the results of this analysis are similar to those from the previous analysis. However, there was a varying efficiency for specific study programs, which is the most pronounced in study programs of Architecture and Computer Engineering and Automation.

In this analysis the average grade and length of studies have a lot more influence on the efficiency of percentage of graduation than secondary school grades and scores on the entrance exam. This confirms the fact that determining efficiency based on the entrance exam is not the most accurate method, both because of its difficulty and the difficulty of studying. This model is more accurate and reliable 
Table 5 DEA analysis of efficiency of studying by measuring the percentage of graduate students using the average grade and length of studies

\begin{tabular}{|c|c|c|c|}
\hline $\mathrm{NO}$ & DMU & Score & $\begin{array}{c}\text { Times as a benchmark for another } \\
\text { DMU }\end{array}$ \\
\hline 1. & Postal Traffic and Telecommunications & 1.000 & 12 \\
\hline 2. & Engineering Management & 0.968 & 0 \\
\hline 3. & Architecture & 0.955 & 0 \\
\hline 4. & Computing and Control Engineering & 0.926 & 0 \\
\hline 5. & Industrial Engineering & 0.768 & 0 \\
\hline 6. & Environmental Engineering & 0.758 & 0 \\
\hline 7. & Traffic and Transport Engineering & 0.735 & 0 \\
\hline 8. & Geodesy and Geomatics & 0.720 & 0 \\
\hline 9. & Graphic Engineering and Design & 0.716 & 0 \\
\hline 10. & Power, Electronic and Telecommunication Engineering & 0.680 & 0 \\
\hline 11. & Mechatronics & 0.612 & 0 \\
\hline 12. & Production Engineering & 0.532 & 0 \\
\hline 13. & Civil Engineering & 0.510 & 0 \\
\hline
\end{tabular}

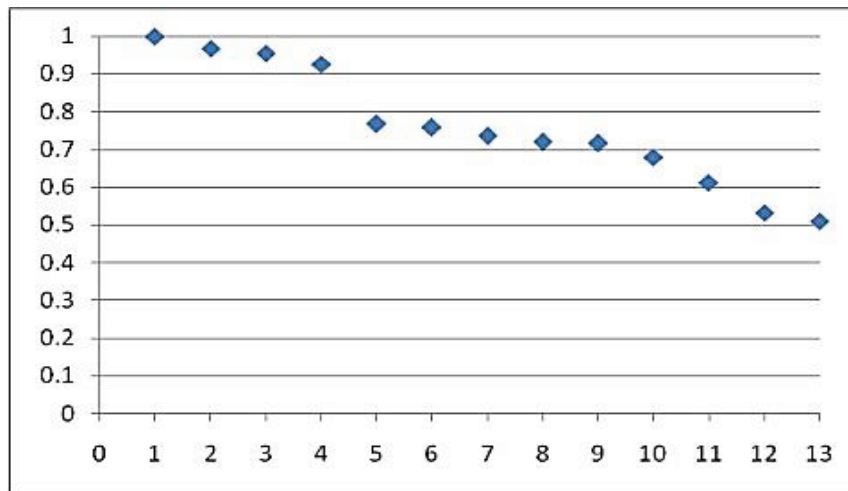

\begin{tabular}{|c|c|}
\hline \multicolumn{2}{|l|}{ Score frequencies } \\
\hline up to 0.10 & 0 \\
\hline $0.10+$ to 0.20 & 0 \\
\hline $0.20+$ to 0.30 & 0 \\
\hline $0.30+$ to 0.40 & 0 \\
\hline $0.40+$ to 0.50 & 0 \\
\hline $0.50+$ to 0.60 & 2 \\
\hline $0.60+$ to 0.70 & 2 \\
\hline $0.70+$ to 0.80 & 5 \\
\hline $0.80+$ to 0.90 & 0 \\
\hline $0.90+$ to 1.00 & 4 \\
\hline Suma: & 13 \\
\hline
\end{tabular}

Figure 5 Graphic presentation of DEA analysis of efficiency of studying by measuring the percentage of graduate students using the average grade and length of studies

\section{Conclusion}

In the decision making process at faculties and universities, this model of measuring the efficiency of teaching process and studying makes an important tool for detecting both the efficiency of respective study programs and each student individually. Based on this analysis appropriate measures can be taken to improve the teaching process or remove specific shortcomings from the study program.

Alternatively, it provides the faculty management bodies and corresponding ministry an appropriate instrument to ensure that relevant personnel has been educated at the lowest cost and whose recently acquired knowledge will benefit the wider community and the Republic of Serbia.

There are significant differences in the efficiency of teaching process, when measured individually for each student and for each program of study. Taking the input parameters of secondary school grade and scores on the entrance exam into account, the best results are achieved by students who enrol to Computer Engineering and Automation and Power, Electronics and Telecommunication Engineering, while the efficiency of studying these programs is the lowest. This may indicate problems in the teaching process: insufficient amount of work invested in these students, there is a large number of students enrolled to these study programs (a large exercise groups), or there is a big difference in the average secondary school grades.

The paper presented multi criteria approach to measuring the efficiency of high school institutions, in this case measuring the efficiency of the teaching process based on DEA analysis, which has proved to be a useful method for measuring and analysing the efficiency in a number of practical problems. Using DEA analysis, the input and output parameters have been divided into subsets of scaled data with the aim to remove the restrictions relating these variables and obtain data that can be used in making subsequent decisions concerning the teaching process.

\section{Acknowledgements}

Author warrants that the article is original, written by stated authors, and has not been published before and it will not be submitted anywhere else for publication prior to acceptance by Technical Gazette.

\section{References}

[1] Charnes, A.; Cooper, W. W.; Rhodes, E. L. Measuring the efficiency of decision making units. // European Journal of Operational Research. 2, (1978), pp. 429-444. https://doi.org/10.1016/0377-2217(78)90138-8

[2] Bifulco, R.; Bretschneider, S. Estimating school efficiency: A comparison of methods using simulated data. // Economics of Education Review. 20, 5(2001), pp. 417-429. https://doi.org/10.1016/S0272-7757(00)00025-X

[3] Drake, L.; Simper, R. The measurement of English and Welsh police force efficiency: A comparison of distance function models. // European Journal of Operational Research. 147, 1(2003), pp. 165-186. https://doi.org/10.1016/S0377-2217(02)00266-7 
[4] Cook, W. D.; Seiford, L. M. Data envelopment analysis (DEA)-Thirty years on. // European Journal of Operational Research. 192, 1(2009), pp. 1-17. https://doi.org/10.1016/j.ejor.2008.01.032

[5] Post, T.; Spronk, J. Performance benchmarking using interactive data envelopment analysis. // European Journal of Operational Research. 115, (1999), pp. 472-487. https://doi.org/10.1016/S0377-2217(98)00022-8

[6] Beasley, J. E. Determining teaching and research efficiencies. // Journal of the Operational Research Society. 46, (1995), pp. 441-452. https://doi.org/10.1057/jors.1995.63

[7] Yun, Y. B.; Nakayama, H.; Tanino, T. Dual approach to generalized data envelopment analysis based on production possibility. // In Proceedings IV ${ }^{\text {th }}$ International Conference on Multi-Objective Programming and Goal Programming: Theory and Applications. MOPGP'00, Ustro'n, Polonia, 2000.

[8] Arcelus, F. J.; Coleman, D. F. An efficiency review of university departments. // International Journal of Systems Science. 28, 7(1997), pp. 721-729. https://doi.org/10.1080/00207729708929431

[9] Cooper, W.; Seiford, L.; Tone, K. Data envelopment analysis: A comprehensive text with models, applications, references and DEA-solver software. Dordrecht: Kluwer Academic Publishers, 2000.

[10] Savić, G.; Martić, M. M.; Krčevinac, S. B. Ograničavanje težina u DEA metodi. SYM-OP-IS '99, XXVI Jugoslovenski simpozijum o operacionim istraživanjima, Beograd, 4.-6. novembar, zbornik radova (15-18). Beograd / Limiting the weights in DEA methods / SYM-OP-IS '99 Yugoslav Symposium on operational research, Belgrade, No v 4-6, Collection of works (15-18), 1999.

[11] Popović, G.; Martić, M. Mogućnosti primene DEA metode za ocenu efikasnosti elektronske trgovine. SYM-OP-I S '02, Jugoslovenski simpozijum o operacionim istraživanjima, Tara (11-19-22) / Possibilities of applying DEA methods for assessing the efficiency of on-line trade SYM-OP-IS '02 Yugoslav Symposium on operational research, Tara (11-19-22), 2002.

[12] Martić, M. M.; Krčedinac, S. B.; Savić, G. Primena DEA metode za Merenje efikasnosti i rangiranje bankarskih filijala. SYM-OP-IS '98, XXV Jugoslovenski simpozijum o operacionim istraživanjima, Herceg Novi, 21.-24. septembra, zbornik radova. (str. 219- 222). Herceg Novi/ Applying DEA methods for measuring the efficiency and ranking of bank subsidiaries/ branches SYM-OP-IS, '98, XXV Yugoslav Symposium on operational research, Herceg Novi, Sept 21-24, Collection of works (pages 219222), 1999.

[13] Pjevčević, D.; Drenovac, D.; Vukadinović, K. Simulacioni model za planiranje obrade rasutog tereta u Luci 'Dunav' Pančevo. u: Simpozijum o operacionim istraživanjima SYMOPIS (XXXIII), Banja Koviljača, str. 445-449, 2006.

[14] Opricović, S. Mogućnosti primene DEA metode prilikom izražavanja preferencije u višekriterijumskoj analizi. SYMOP-IS '98, XXV Jugoslovenski simpozijum o operacionim istraživanjima, Herceg Novi, 21.-24. septembra, zbornik radova (str. 945-949). Herceg Novi / Possibilities of using DEA methods when expressing preferences in multi-criteria analysis, SYM-OP-IS, '98, XXV Yugoslav Symposium on operational research, Herceg Novi, Sept 21-24, Collection of works (pages 945-949), 1998.

[15] www. oecd.org/edu

[16] Golany, B.; Roll, Y. Incorporating standards via data envelopment analysis. In: Charnes, A., Cooper, W.W., Lewin, A., Seiford, L. (Eds.), Data Envelopment Analysis: Theory, Methodology and Applications. Kluwer Academic, Boston, MA, pp. 313-328, 1994. https://doi.org/10.1007/978-94-011-0637-5_16

[17] Dyson, R. G.; Thanassoulis, E. Reducing weight flexibility in DEA. // Journal of Operational Research Society. 39, 6(1988), pp. 563-576. https://doi.org/10.1057/jors. 1988.96

[18] Bojanic, R.; Perovic, V.; Nerandžić, B.; Šikoparija, T.; Bulatovic, B. Integrated BSC and DEA Models in the Function of Measuring the Success of the Teaching Process. // Metalurgia international. No. 3(20139, pp. 4449.

[19] Caballero, R.; Galache, T.; Gomez, T.; Molina, J.; Torrico, A. Budgetary allocations and efficiency in the human resources policy of a university following multiple criteria. // Economics of Education Review. 23, (2004), pp. 67-74. https://doi.org/10.1016/S0272-7757(03)00049-9

\section{Authors' addresses}

Prof. dr Veselin Perovic

University of Novi Sad, Faculty of Technical Sciences Trg Dositeja Obradovica 6

21000 Novi Sad, Serbia

E-mail: vesa@uns.ac.rs

Doc. Dr Ranko Bojanic

University of Novi Sad, Faculty of Technical Sciences

Trg Dositeja Obradovica 6

21000 Novi Sad, Serbia

E-mail: bojanic@uns.ac.rs

Prof. dr Branislav Nerandzic

University of Novi Sad, Faculty of Technical Sciences Trg Dositeja Obradovica 6

21000 Novi Sad, Serbia

E-mail: branen@uns.ac.rs 